Chalapathi C. Rao MD, Stephen F. Dierdorf MD, Thomas M. Wolfe MD, Kenneth A. Haselby MD, Gopal Krishna MD, Raymond R. Paradise, PHD

\title{
Effect of age on epinephrine-induced arrhythmias during halothane anaesthesia in pigs
}

The effect of age on the arrhythmogenicity of epinephrine during halothane anaesthesia was studied in pigs of two different age groups. At a stable alveolar concentration of 0.84 volumes per cent halothane, ventricular arrhythmias could not be elicited in one- to three-day-old pigs by a $100 \mu \mathrm{g} \cdot \mathrm{kg}^{-1}$ infusion of epinephrine. PVCs were pro. duced in 50- to 55-day-oid pigs at a mean epinephrine dose of $9.55 \mu \mathrm{g} \cdot \mathrm{kg}^{-1}$. Heart rate, systolic blood pressure, and rate-pressure product were significanty higher before and during the epineptrine infusion in the 50- to 55-day-nld pigs. It is concluded that there is an age dependent effect upor opinephrine induced arrhythmias during halothane anaesthesia in pigs.

\section{Key words}

ANAESTHETICS, VOLATILE: halothane; HEART, arrhythmia: epinephrine; AGE FACTORS: halothane; ANAESTHESIA, paediatric.

It is well known that halothane anaesthesia increases the sensitivity of the myocardium to the arrhythmogenic effects of epinephrine. ' Clinical experience indicates that epinephrine infiltration of the surgical site in young children may produce sinus tachycardia, but rarely results in significant ventricular arrhythmias such as frequent premature ventricular contractions (PVCs), coupled PVCs, or multiform PVCs. ${ }^{2}$ The present study was undertaken to determine if these clinical observations could be

From the Department of Anesthesia, Indiana University School of Medicine, Indianapolis, Indiana.

Address correspondence to: Stephen F. Dierdorf MD, 1120 South Drive, Feslcr Hall 204, Indianapolis, Indiana 46223. verified under more controlled conditions using an experimental animal model.

\section{Methods}

We studied two groups of crossbred pigs of different ages in a manner similar to that used by Chapin ${ }^{3}$ and Schick ${ }^{4}$ in dogs. Five pigs ages one to three days comprised the younger group, and five pigs ages 50 to 55 days comprised the older group. In each experiment anaesthesia was induced with halothane in 60 per cent nitrogen and 40 per cent oxygen. Tracheal intubation was performed without the use of other drugs. A femoral artery and an external jugular vein were cannulated and an infusion of five per cent dextrose in lactated Ringers' solution was administered at a rate of $5 \mathrm{ml} \cdot \mathrm{kg}^{-1} \cdot \mathrm{hr}^{-1}$ for the duration of the experiment. Ventilation was controlled with a volume-limited ventilator. Using frequent arterial blood gas determinations the ventilator was adjusted until the arterial $\mathrm{PCO}_{2}$ was stabilized betwecn 4.6 and $5.3 \mathrm{kPa}$ (35 to 40 torr). Base deficits greater than $2 \mathrm{mmol} \cdot \mathrm{l}^{-1}$ were corrected with sodium bicarbonate. ${ }^{5}$ The inspired halothane concentration was adjusted until a stable alveolar concentration of $0.84 \pm 0.08$ volumes per cent ( $1.4 \mathrm{MAC}$ for the 50 to 55 day old pigs, unpublished data) was established. Oesophageal temperature was monitored and maintained between 37 and 39 degrees Celsius. After 60 minutes of stable anaesthesia control measurements of arterial blood pressure, heart rate, arterial halothane concentration, and arterial $\mathrm{PO}_{2}$, $\mathrm{PCO}_{2}$, and $\mathrm{pH}$ were made. Epinephrine was then administered via a peripheral vein by an infusion pump at a rate of $10 \mu \mathrm{g} \cdot \mathrm{kg}^{-1} \cdot \mathrm{min}^{-1}$ for ten minutes (preliminary studies had revealed that this infusion rate was required to produce arrhythmias in the 50- 
TABLE

\begin{tabular}{llcc}
\hline & & $\begin{array}{c}\text { Group I } \\
(1-103 \text {-doy-old pigs }) \\
N=5 ; \text { weight }=1.4 \pm 0.25 \mathrm{~kg}\end{array}$ & $\begin{array}{c}\text { Group II } \\
(50-10.55 \text {-day-old pigs }) \\
N=5 ; \text { weight }=13.1 \pm 4.0 \mathrm{~kg}\end{array}$ \\
\hline Control & HR & $146 \pm 17$ & $148 \pm 23$ \\
& SBP & $57=12$ & $119 \pm 6$ \\
Epinephrine & RPP & $8,391=2213$ & $17,599 \pm 2620$ \\
& HR & $128=17$ & $170 \pm 33$ \\
& SBP & $137=19$ & $175 \pm 27$ \\
& RPP & $17,631 \pm 3429$ & $28,891 \pm 3733$ \\
\hline
\end{tabular}

Effects of epinephrine on heart rate (HR), systolic blood pressure (SBP), and rate-pressure product $(R P P)$ in two different age groups of pigs. All values are mean $\pm S D$.

to 55-day-old pigs). Continuous tracings of the lead II electrocardiogram and arterial blood pressure were made throughout the ten-minute epincphrine infusion. From these recordings systolic blood pressure (SBP), heart rate (HR), and the infusion time and epinephrine dose to the appearance of coupled PVCs were determined. HR, SBP, and rate-pressure product $(\mathrm{RPP}=\mathrm{SBP} \times \mathrm{HR})$ were compared between groups using a Student's t-test as well as between control and after epinephrine within each group using a paired t-test.

\section{Results}

Premature ventricular contractions were not seen in any of the one-to three-day-old pigs despite the administration of $100 \mu \mathrm{g} \cdot \mathrm{kg}^{-1}$ of epinephrine over ten minutes. All of the 50- to 55-day-old pigs developed ventricular arrhythmias with the dose of epinephrine (mean \pm SD) to produce coupled PVC's being $9.55 \pm 3.8 \mu \mathrm{g} \cdot \mathrm{kg}^{-1}$ (mean infusion time of 57.3 seconds). The dose of epinephrine required to produce three or more consecutive PVCs in the 50- to 55-day-old pigs was $10.7 \neq$ $3.5 \mu \mathrm{g} \cdot \mathrm{kg}^{-1}$ (mean infusion time of 64 seconds). The difference in the incidence of ventricular arrhythmias between the two groups was significant ( $p<0.02)$ using the Chi-square test.

Control cardiovascular parameters were compared between groups (Table). Cardiovascular changes were also compared at the appearance of PVCs in the 50- to 55-day-old group and after 57 seconds of epinephrine infusion in the one- to three-day-old group. Control heart rate was not significantly different between the two age groups. SBP and RPP were significantly greater in the 50- to 55-day-old pigs (SBP, $p<0.0005$; RPP, $p<0.0005$ ) Epinephrine significantly increased heart rate $(\mathrm{p}<$ $0.025)$, SBP ( $p<0.0125$ ), and RPP ( $<<0.0005)$ in the 50- to 55-day-old pigs. Epinephrine also increased SBP ( $p<0.0005)$ and RPP ( $p<0.0025)$ but decreased heart rate $(p<0.05)$ in the one- to three-day-old pigs.

\section{Discussion}

The results of this study confirm in the pig the clinical impression that age-related differences exist in the arrhythmogenicity of epinephrine during halothane anaesthesia.

Since MAC is higher in younger animals than older animals it could be argued that the one- to three-day-old pigs were not anaesthetized as deeply as the 50-to 55-day-old pigs. One would, however, speculate that light anaesthesia would give rise to more anhythmias due to sympathetic nervous system stimulation. This did not occur. If the 50- to 55-day-old pigs were more deeply anaesthetized, it would be expected that less arrhythmias should occur. ${ }^{6}$ We selected an equal anaesthetic concentration for both groups so the hearts would be exposed to similar halothane concentrations.

Although this study was not designed to delineate the mechanism of the arrhythmias, certain speculations can be made. Zink found that both an elevated blood pressure and an elevated heart rate can induce

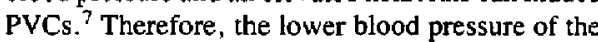
one- to three-day-old pigs would be expected to result in a lower incidence of arrhythmias. ${ }^{8-10}$ Although we did not measure awake blood pressures in our animals, our values are similar to blood pressures found in other studics during anaes- 
thesia. ${ }^{11,12}$ Previously reported systolic blood pressures for conscious one- to three-day-old pigs was 70 torr ${ }^{13}$ Our one- to three-day-ald pigs were not, therefore, significantly hypotensive.

The two primary mechanisms of ventricular arrhythmias are re-entry and increased automaticity. From our protocol no conclusions can be made concerning automaticity. Some inferences can be made about re-entry. It has been suggested that re-entry is the most likely cause of epinephrine induced arrhythmias during halothane anaesthesia. Epinephrine potentiates the slowing of ventricular conduction produced by halothane and consequently enhances the potential for re-entry. ${ }^{7,14}$ Buckley showed in pigs less than one week old that the effect of epinephrine was predominantly alpha adrenergic with both peripheral and myocardial beta adrenergic mechanisms being immature. ${ }^{10}$ This may explain why the heart rate of the one- to three-day-old pigs did not increase in response to epinephrine. The lack of arrhythmias in the one- to three-day-old pigs may also be related to the smaller size of their hearts. Re-entry excitation requires a critical length of the conduction pathway. The hearts of the one- to three-day-old pigs may not have a conduction pathway that achieves critical length.

Younger animals are more susceptible to the myocardial depressant effects of halothane. ${ }^{15}$ It would be anticipated that increased myocardial depression would decrease the likelihood of epinephrine arrhythmias.

The dose of epinephrine required to induce PVCs in the 50- to 55 -day-old pigs $\left(9.55 \pm 3.8 \mu \mathrm{g} \cdot \mathrm{kg}^{-1}\right)$ was considerably higher than the $3.5 \mu \cdot \mathrm{kg}^{-1}$ requited in Schick's study which used adult dogs. This difference may be secondary to either species variation or could be a further manifestation of an agc effect. The adult dog is physiologically older than the 50- to 55-day-old pig. The dose of epinephrine required in our study with pigs was not substantially different from that reported in human children by Karl et al. ${ }^{16}$ They reported infiltrated doses of $15.7 \mu \mathrm{g} \cdot \mathrm{kg}^{-1}$ of epinephrine without arrhythmias. For comparison Johnston reported an arrhythmogenic epinephrine dose of $2.1 \mu \mathrm{g} \cdot \mathrm{kg}^{-1}$ during halothane anaesthesia in human adults. ${ }^{77}$ The pig may indeed be a better model than the dog for comparison to humans. ${ }^{18}$

This study substantiates the clinical observation that there is an age-related difference in the susceptibility to epinephrine induced arrhythmias during halothane anaesthesia. Further studies are required to elucidate the mechanism for this difference.

\section{References}

1 Katz RL, Bigger $J F$. Cardiac arrhythmias during anesthesia and operation. Anesthesiology 1970; 33: 193213.

2 Melgrave AP. The use of epinephrine in the presence of halothane in children. Can Anaesth Soc J 1970; 17: 256-60.

2 Chapin JC, Kushins LG, Munson ES, Schick LM. Lidocaine, bupivacaine, etidocaine, and epinephrineinduced arrhythmias during halothane anesthesia in dogs. Anesthesiology 1980; 52: 23-6.

4 Schick LM, Chapin JC, Munson ES, Kushins LG. Pancuronium, d-tubacurarine, and epinephrine induced arrhythmias during halothane anesthesia in dogs. Anesthesiology 1980; 52: 207-9.

5 Ruiz $B C, T$, ucker $W K$, Kirby $R R$. A program for the calculation of intrapulmonary shuts, blood gas, and acid-basc values for a programmable calculator. Anesthesiology 1975; 42: 88-95.

6 Joas TA, Stevers WC. Comparison of the arrhythmic doses of epinephrine during forane, halothane, and fluroxene anesthesia in dogs. Anesthesiology 1971; 35: 48-53.

7 Zink J, Sasynuik BI, Dresel PE. Halothane-epinephrine induced cardiac arthythmias and the role of heart rate. Anesthesiology 1975; 45: 548-55.

8 Crane L, Gootman N. Gootman PM. Age-dependent cardiovaseular effects of halothane anesthesia in neonatal pigs. Arch Tnt Pharmacodyn 1975; 214: 180-7.

9 Rowe MI, Arango A. A critical appraisal of two "neonatal" experimental subjects. J. Pediatr Surg 1977; 12 . 409-12.

10 Buckley NM, Gootman PM, Yellin EL, Brazeau P. Age-related cardiovascular effects of catechol.umines in anesthetized pigs. Citc Res 1979; 45: 282-91.

11 Evans JR, Rowe RD, Downie HG, Rowsell HC. Murmurs arising from the ductus arteriosus in normal newborn swine. Circ Res 1963; 12: 85-93.

12 Buckley NM, Gootman PM, Gootman N, Reddy $G D$, Weaver LC, Crane LA. Age-dependent cardiovascular effects of afferent stimulation in neonatal pigs. Biol Neonate 1976; 30: 268-79.

13 Engelhardt $W V$. Swine cardiovascular physiology a review. In: Bustad LK, McClellan RO, editors. 
Swine in biomedical research. Battelle-Northwest, Richland, Washington USA 1966: 307-29.

14 Hashimoto $K$, Endoh $M$, Kimura T. Hashimoto $K$. Effects of halothane on automaticity and contractile force of isolated blood-perfused canine ventricular tissue. Anesthesialogy 1975; 42: 15-25.

15 Cook DR, Brandom BW. Shiu $G$, Wolfson $B$. The inspired median effective dose, brain concentration at anesthesia, and cardiovascular index for halothane in young rats. Anesth Analg 1981; 60: 182-85.

16. Karl $H W$, Swedlow $D B$, Lee $K W$, Downes JJ, Epjrephrine-halothane interactions in children. Anesthesiology 1983; 58: 142-5.

17 Johnston RR, Eger EI, Wilson C. A comparative interaction of epinephrine with enflurane, isoflurane, and halothane in man. Anesth Analg 1976; 55: 709-12.

18 Dodds WJ, $H s u C-K$. Introductions: strengths and limitations of the pig as an animal model, In: Dodds WJ. The pig model for biomedical research. Fed Proc 1982; 41: 247-56.
Résumé

On a étudié l'arythmogénicité de la combinaison épinéphrine/halothane chez des porcs d'âges differrents. Sous anesthésie stable, à 0.84 vol\% d'halothane alvéolaire, aucune arythmie ventriculaire n' a puêtre déclenchée par l'infusion de $100 \mu \mathrm{g}^{\prime} \mathrm{kg}^{-1}$ d'épinéphrine chez des porcs agés d' un à trois jours; d'autre part, chez des porcs âgés de 50 à 55 jours, des extrasystoles ventriculaires ont pue être déclenchées à des doses moyennes d'epinéphrine de 9.55 $\mu g \cdot \mathrm{kg}^{-1}$. La fréquence cardiaque, la pression artérielle et le produit fréquence/pression étaients plus élevés de façon significative avant et pendant l'infusion d'épinéphrine. On en conclut que l'âge de l'animal joue un rôle dans la genèse des arythmies attribuables à la combinaison Épinéphrinethalothane. 